\section{Moss Control on Creeping Bentgrass Greens with Standard and Alternative Approaches}

\author{
Megan M. Kennelly ${ }^{1}$ and Timothy C. Todd \\ Department of Plant Pathology, Kansas State University, 4024 \\ Throckmorton PSC, Manhattan, KS 66506 \\ Derek M. Settle \\ Chicago District Golf Association, Midwest Golf House, 11855 Archer \\ Avenue, Lemont, IL 60439
}

\section{Jack D. Fry \\ Department of Horticulture, Forestry, and Recreation Resources, Kansas State University, Manhattan, KS 66506}

Additional index words. Bryum argenteum, silvery thread moss, carfentrazone-ethyl, integrated pest management, sodium bicarbonate

\begin{abstract}
Moss is common on creeping bentgrass (Agrostis stolonifera L.) putting greens, and more control options are needed. Spot treatment of sodium bicarbonate $\left(44.2 \mathrm{~g} \cdot \mathrm{L}^{-1}\right)$ was compared with broadcast sprays of carfentrazone-ethyl (50.5 or $101 \mathrm{~g}$ a.i./ha), chlorothalonil ( $8.2 \mathrm{or} 12.8 \mathrm{~kg}$ a.i./ha) and a tank mixture of chlorothalonil, mancozeb, and thiram (8.2, 9.8, and $11.5 \mathrm{~kg}$ a.i./ha) in 2006 in Lemont, IL. Sodium bicarbonate suppressed moss growth equally as the conventional products. These results led to further experiments in $\mathbf{2 0 0 8}$ in which moss suppression was evaluated within standard and alternative putting green management regimes in Manhattan, KS, and Lemont, IL. The standard approach included spring and fall applications of carfentrazone-ethyl (101 $\mathrm{g}$ a.i./ha) for moss control, biweekly applications of urea $(46 \mathrm{~N}-0 \mathrm{P}-0 \mathrm{~K})$ at $15 \mathrm{~kg} \mathrm{~N} / \mathrm{ha}$, and applications of chlorothalonil $(8.2 \mathrm{~kg}$ a.i./ha) on a 14-day interval. Conversely, the alternative approach included spring and fall spot treatments of sodium bicarbonate $\left(44.2 \mathrm{~g} \cdot \mathrm{L}^{-1}\right)$ for moss control, biweekly applications of a natural organic fertilizer $(8 \mathrm{~N}-$ $1 \mathrm{P}-3 \mathrm{~K})$ to provide nitrogen at $15 \mathrm{~kg} \mathrm{~N} / \mathrm{ha}$, and applications of chlorothalonil $(8.2 \mathrm{~kg} \mathrm{a} . \mathrm{i}$. ha) only when dollar spot reached a predetermined threshold level. Standard and alternative regimes were compared at both 3.2 - and $4.0-\mathrm{mm}$ mowing heights; synthetic and organic fertilizers applied alone without pest control approaches were included as controls. In Kansas and Illinois, moss coverage using the alternative management regime was not significantly different from that on greens managed using the standard regime. In Kansas, moss severity at a $3.2 \mathrm{~mm}$ was 1.6 -fold higher than at the $4.0-\mathrm{mm}$ height. In Illinois, sodium bicarbonate suppressed moss equivalently to the carfentrazone-ethyl treatment, and in the fertilizer-only controls, mowing at 3.2 versus $4.0 \mathrm{~mm}$ led to more moss coverage. These studies demonstrate that moss can be effectively suppressed on greens using spot applications of sodium bicarbonate and reduced moss encroachment is possible with higher mowing heights.
\end{abstract}

Mosses are considered as common weeds on golf course putting greens across the United States (Cook et al., 2002; Happ, 1998; Yelverton, 2005). Mosses are nonvascular plants with two developmental stages of a small, diploid sporophyte and a larger, haploid gametophyte (Buck and Goffinet, 2000). Although silvery-thread moss (Bryum argenteum Hedw.) is the most common moss species observed on greens, other species have been observed such as Bryum lisae, Amblystegium serpens, and Entodon seductrix (Borst et al., 2008; Dernoeden, 2002; Happ, 1998). In greens, moss is problematic because the cushiony gametophyte colonies disrupt appearance, surface uniformity, and ball roll.

A number of researchers have tested the efficacy of various products for moss control, including synthetic pesticides, nutrient-based
Burnell et al. (2004) observed that spotapplied dishwashing soap controlled moss in creeping bentgrass greens but resulted in lower turfgrass quality. In contrast, moss control was not observed with dishwashing soap in creeping bentgrass and velvet bentgrass (Cook et al., 2002) or green-height turf (species not given) (Landschoot and Cook, 2005).

Chlorothalonil (tetrachloroisophthalonitrile), a commonly used turfgrass fungicide, did not reduce moss on an experimental 'Penncross' creeping bentgrass research green in Ohio (Taylor and Danneberger, 1996) nor in a study in Oregon (Cook et al., 2002). In contrast, in a study at two golf courses in North Carolina, two rates of two formulations of chlorothalonil (chlorothalonil at 9.1 and $18.2 \mathrm{~kg}$ a.i./ha and chlorothalonil plus zinc at 9.5 and $17.4 \mathrm{~kg}$ a.i./ha) at two spray volumes (2038 and $4076 \mathrm{~L} \cdot \mathrm{ha}^{-1}$ ) led to variable but significant moss reductions in 'Penncross' creeping bentgrass greens (Burnell et al., 2004). Carfentrazone-ethyl \{[ethyl 2-chloro-3-(2-chloro-4-fluoro-5-[4-(difluoromethyl)-4,5-diydro-3-methyl-5-oxo-1H-1,2,4trizol-1-yl)phenyl] propanoate $\}$ is a contact herbicide labeled for postemergence control of broadleaf weeds and $B$. argenteum in turfgrass (QuickSilver T\&O Herbicide; FMC Corporation, Philadelphia, PA). Carfentrazoneethyl is in the triazolinone class, and the mode of action involves interference with chlorophyll biosynthesis and the disruption of plant cell membranes (Turgeon et al., 2009). Approximately 2002, spot applications of dry sodium bicarbonate were used by some superintendents in the Chicago, IL, area (R.T. Kane, Chicago District Golf Association, Lemont, IL; personal communication; 2008). Researchers in Pennsylvania tested sodium bicarbonate dissolved in water at a rate of 37 to $55 \mathrm{~g} \cdot \mathrm{L}^{-1}$ and found it was an effective spot-treatment drench for moss control (Landschoot and Cook, 2005). Sodium bicarbonate could potentially be a lower risk alternative for use in moss control, but more information on its efficacy is needed.

There are also gaps in knowledge regarding other cultural practices and their impacts on moss. For example, low nitrogen has been linked to increased moss severity (Hummel, 1994; Borst et al., 2009), but the impact of nitrogen source, and particularly organic nitrogen, on moss is not known. Low mowing heights have also been associated with moss problems in greens (Beard, 2002; Cook et al., 2002; Dernoeden, 2002), but replicated studies are lacking on the effects of mowing height on moss encroachment and control.

Golf course superintendents are under increasing pressure to be environmentally conscious and to use management and pest control practices that result in fewer pesticide applications and which reduce impact on surface or groundwater quality. More information is needed on potential alternative moss control strategies. Therefore, the first objective was to investigate the potential moss control efficacy from sodium bicarbonate compared with several conventional pesticide treatments. Second, 
moss responses were measured on greens managed using standard versus alternative practices at two mowing heights. More specifically, the standard regime evaluated moss responses in creeping bentgrass plots receiving carfentrazone-ethyl for moss suppression, a synthetic nitrogen source, and a calendar-based fungicide application schedule. The alternative regime evaluated moss development on turf receiving sodium bicarbonate spot sprays, an organic nitrogen source, and a threshold-based fungicide application schedule.

\section{Materials and Methods}

Initial moss suppression study, 2006. Three carfentrazone-ethyl treatments, three fungicide treatments, one sodium bicarbonate treatment, and an untreated control were evaluated on a USGA-constructed green seeded Oct. 2002 with 'L-93'/'G-2' (50:50) creeping bentgrass at the Chicago District Golf Association's (CDGA) Sunshine Golf Course in Lemont, IL. The root zone was sand-based with a $\mathrm{pH}$ of 7.8 and organic matter of $0.51 \%$. The turf was mowed $6 \mathrm{~d}$ per week at $4.1 \mathrm{~mm}$, irrigated as needed (no hand watering), and fertilized with nitrogen $(\mathrm{N})$ at $193 \mathrm{~kg} \cdot \mathrm{ha}^{-1} /$ year. On $21 \mathrm{Apr}$. 2006, a 10.2-cm diameter cup cutter was used to transfer plugs containing moss from a naturally-infested green at CDGA. The predominant moss in the Lemont greens was identified as a Bryum species, either Bryum caespiticium or Bryum lisae var. cuspidatem, based on gametophyte morphology (Malcolm Sargent, University of Illinois, Department of Plant Biology, Urbana, IL, personal communication, 2009; A. Jonathan Shaw, Duke University, Department of Biology, Durham, NC, personal communication, 2009). Persistent lack of sporophyte structures made further identification difficult, because most Bryum species cannot be identified without the sporophyte (Malcolm Sargent and A. Jonathan Shaw, personal communication). Moss-infested plugs were transplanted into the center of each experimental plot, and the initial di-

Received for publication 7 Jan. 2010. Accepted for publication 2 Mar. 2010.

This manuscript is contribution 09-392-J of the Kansas Agricultural Experiment Station, Manhattan, KS.

We thank Dr. Randy Kane [Chicago District Golf Association (CDGA), Lemont, IL] for valuable discussions related to this work and Keith Rincker (CDGA) and Andrew Lance (Kansas State University, Manhattan, KS) for technical support. We thank Dr. A. Jonathan Shaw (Department of Biology, Duke University, Durham, NC) and Dr. Malcolm Sargent (Department of Plant Biology, University of Illinois, Urbana, IL) for identification of moss samples from Manhattan, KS, and Lemont, IL. We also thank the USGA's Turfgrass and Environmental Research Program (U.S. Golf Association-Green Section Research, Stillwater, OK) and the Kansas Turfgrass Foundation (Manhattan, KS) for partially funding this work.

${ }^{1}$ To whom reprint requests should be addressed; e-mail kennelly@ksu.edu. ameter of each moss colony was measured. Plots measured $1.2 \times 1.8 \mathrm{~m}$ and were arranged in a randomized complete block design with three replications.

Three treatments were applied only in the spring, on 27 Apr., and again 1 week later. Sodium bicarbonate (Pure Baking Soda; Arm and Hammer, Princeton, NJ) was applied as spot sprays at $44.2 \mathrm{~g} \cdot \mathrm{L}^{-1}$ using a hand-spray bottle to deliver enough solution to visibly moisten the colony $(\approx 2 \mathrm{~mL}$ per moss plug). Carfentrazone-ethyl (Quicksilver T\&O Herbicide; FMC Corp., Philadelphia, PA) was applied at 50.5 and $101 \mathrm{~g}$ a.i./ha. A third carfentrazone-ethyl treatment, at the rate of $101 \mathrm{~g}$ a.i./ha, was applied on the previously stated spring dates and on 19 Sept. and 4 Oct. The three fungicide treatments were applied every $14 \mathrm{~d}$ from 21 Apr. through 4 Oct. for a total of 12 applications. Chlorothalonil (Daconil Ultrex 82.5 WDG; Syngenta Crop Protection Inc., Greensboro, NC), was applied at either 8.2 or $12.8 \mathrm{~kg}$ a.i./ha. The third fungicide treatment was a tank mixture of chlorothalonil, mancozeb (Fore 80 WP; Dow AgroSciences, Indianapolis, IN) and thiram (Spotrete 75 WDG; Cleary Chemical Corp., Dayton, NJ) at $8.2,9.9$, and $11.6 \mathrm{~kg}$ a.i./ha, respectively. The fungicides and the carfentrazone-ethyl were applied with a $\mathrm{CO}_{2}$-powered backpack sprayer with 8004 TeeJet nozzles (Spraying Systems Co., Wheaton, IL) at $241 \mathrm{kPa}$ in water equivalent to $828 \mathrm{~L} \cdot \mathrm{ha}^{-1}$. All plots were not irrigated for at least $12 \mathrm{~h}$ after application.

Every 2 weeks, preceding treatment applications, moss colony diameter was measured. Area under the curve (AUC) analysis was performed on moss colony diameter to give a cumulative, season-long indication of moss pressure (see area under the disease progress curve; Madden et al., 2007). Moss AUC data were subjected to analysis of variance using the PROC MIXED procedure of the Statistical Analysis System (Cary, $\mathrm{NC})$. The AUC data and individual rating date means were separated using Fisher's least significant difference test at $P \leq 0.05$. Preliminary findings from this 2006 trial have been summarized in a nonpeer-reviewed format (Settle et al., 2008).

Standard versus alternative management regimes in Illinois and Kansas, 2008. Based on the results of the first study, a second experiment was conducted to further investigate the potential moss control activity of sodium bicarbonate as part of an overall green management program. Studies using identical treatments, but reversed treatment structure, were established in Manhattan, KS, and Lemont, IL, to evaluate standard and alternative treatments for their effects on moss suppression. At both sites, the standard approach included spring and fall applications of carfentrazone-ethyl (101 g a.i./ha) for moss control, biweekly applications of urea $(46 \mathrm{~N}-0 \mathrm{P}-0 \mathrm{~K})$ at $15 \mathrm{~kg} \mathrm{~N} / \mathrm{ha}$ (hereafter referred to as synthetic), and applications of chlorothalonil (8.2 kg a.i./ha) on a $14-\mathrm{d}$ interval. Conversely, the alternative approach included spring and fall spot treatment of sodium bicarbonate $\left(44.2 \mathrm{~g} \cdot \mathrm{L}^{-1}\right)$ for moss control, biweekly applications of a natural organic fertilizer (described subsequently and hereafter referred to as organic) to provide $\mathrm{N}$ at $15 \mathrm{~kg} \cdot \mathrm{ha}^{-1}$, and applications of chlorothalonil (8.2 kg a.i./ha) only when dollar spot reached a predetermined threshold level (5\% severity). Standard and alternative management regimes were compared at both 3.2and 4.0-mm mowing heights; synthetic and organic fertilizers were applied alone without pest control approaches to serve as controls.

Lemont, IL. In Lemont, the study was conducted on the CDGA green described previously. On 13 May 2008, a 10.2-cm diameter cup cutter was used to transfer two moss colonies to the center of each plot, spaced $30 \mathrm{~cm}$ apart, and the initial diameter of each moss colony was measured. All initial colonies were at least $8.9 \mathrm{~cm}$ in diameter. The experiment was arranged as a split-plot, randomized complete-block design with four replications. The whole plot factor was mowing height, either 3.2 or $4.0 \mathrm{~mm}$. Whole plots were $3.0 \times 1.8 \mathrm{~m}$. Mowing was performed $6 \mathrm{~d}$ per week with the entire area mowed using a triplex Toro Greensmaster 3000 (The Toro Company, Bloomington, $\mathrm{MN}$ ) set at $4.0 \mathrm{~mm}$, and then a Toro Greensmaster 1000 walkbehind mower was used on plots maintained at $3.2 \mathrm{~mm}$. The split-plot factor included four fertility/chemical treatments: 1) organic fertilizer alone; 2) alternative management regime; 3) synthetic fertilizer alone; or 4) the standard management regime.

The organic fertilizer, Sustane (Sustane, Cannon Falls, MN) (8N-1P-3K), was composed of composted turkey litter, hydrolyzed feather meal, corn gluten meal, and sulfate of potash. Sustane was applied using a handheld shaker bottle. The synthetic $\mathrm{N}$ source was urea $(46 \mathrm{~N}-0 \mathrm{P}-0 \mathrm{~K})$. Fertilizers were applied nine times to provide $\mathrm{N}$ at $15 \mathrm{~kg} \cdot \mathrm{ha}^{-1}$ on 30 May; 11 and 24 June; 9 and 21 July; 5 and 19 Aug.; and 1 and 17 Sept. Urea was applied in a spray solution of $828 \mathrm{~L} \cdot \mathrm{ha}^{-1}$ using a $\mathrm{CO}_{2^{-}}$ powered handheld boom sprayer pressurized at $241 \mathrm{kPa}$ and delivered through XR TeeJet 8004VS nozzles. The phosphorus $(\mathrm{P})$ and potassium (K) sources were applied to plots receiving urea applications to match levels applied to plots receiving the organic $\mathrm{N}$ source; the $\mathrm{P}$ source was $0 \mathrm{~N}-8 \mathrm{P}-0 \mathrm{~K}$ and $\mathrm{K}$ source $0 \mathrm{~N}-0 \mathrm{P}-50 \mathrm{~K}$. The $\mathrm{P}$ and $\mathrm{K}$ were applied as granules, and $\approx 50 \mathrm{~g}$ of dry sand was mixed with them in the shaker bottle before application to improve distribution uniformity. Irrigation was applied within 1 to $2 \mathrm{~h}$ of fertilizer application.

For the standard and alternative regimes, sodium bicarbonate and carfentrazone-ethyl, respectively, were applied on 20 and 30 May and on 17 Sept. and 1 Oct. Sodium bicarbonate was applied at $44.2 \mathrm{~g} \cdot \mathrm{L}^{-1}$ using the spot-spray method described previously. Carfentrazone-ethyl at $101 \mathrm{~g}$ a.i./ha was applied using a $\mathrm{CO}_{2}$-powered boom sprayer equipped with XR TeeJet 8004VS nozzles at $241 \mathrm{kPa}$ in water equivalent to $828 \mathrm{~L} \cdot \mathrm{ha}^{-1}$. Chlorothalonil was applied at $8.2 \mathrm{~kg}$ a.i./ha every 2 weeks with the first application on 20 May and the final application on 1 Oct. in the 


\begin{tabular}{|c|c|c|c|c|c|c|c|c|}
\hline \multirow[b]{2}{*}{ Treatment and rate } & \multirow[b]{2}{*}{ Spray timing } & \multicolumn{7}{|c|}{ Moss diam $(\mathrm{cm})^{y}$} \\
\hline & & 14 June & 10 Aug. & 23 Aug. & 19 Sept. & 5 Oct. & 16 Oct. & $\mathrm{AUC}^{\mathrm{x}}$ \\
\hline Sodium bicarbonate $44 \mathrm{~g} \cdot \mathrm{L}^{-1} \mathrm{w}$ & Spring & $1.7 \mathrm{c}$ & $0.8 \mathrm{~cd}$ & $0.0 \mathrm{~b}$ & $1.3 \mathrm{~cd}$ & $0.8 \mathrm{~b}$ & $1.3 \mathrm{bc}$ & $18.4 \mathrm{~b}$ \\
\hline Carfentrazone-ethyl $50.5 \mathrm{~g}$ a.i./ha & Spring & $5.9 \mathrm{ab}$ & $4.2 \mathrm{bc}$ & $3.8 \mathrm{ab}$ & $4.7 \mathrm{bcd}$ & $4.2 \mathrm{~b}$ & $5.9 \mathrm{abc}$ & $59.9 \mathrm{~b}$ \\
\hline Carfentrazone-ethyl $101 \mathrm{~g}$ a.i./ha & Spring + fall & $3.4 \mathrm{bc}$ & $0.4 \mathrm{~d}$ & $1.9 \mathrm{~b}$ & $6.8 \mathrm{ab}$ & $5.9 \mathrm{ab}$ & $3.4 \mathrm{bc}$ & $49.5 \mathrm{~b}$ \\
\hline Chlorothalonil $8.2 \mathrm{~kg}$ a.i. $/ \mathrm{ha}$ & $14 \mathrm{~d}$ & $2.5 \mathrm{bc}$ & $1.7 \mathrm{~cd}$ & $1.3 \mathrm{~b}$ & $2.5 \mathrm{bcd}$ & $6.4 \mathrm{ab}$ & $2.5 \mathrm{bc}$ & $51 \mathrm{~b}$ \\
\hline Chlorothalonil $12.8 \mathrm{~kg}$ a.i./ha & $14 \mathrm{~d}$ & $0.8 \mathrm{c}$ & $0.0 \mathrm{~d}$ & $0.0 \mathrm{~b}$ & $0.8 \mathrm{~d}$ & $2.5 \mathrm{~b}$ & $2.1 \mathrm{bc}$ & $34.3 \mathrm{~b}$ \\
\hline
\end{tabular}

${ }^{\mathrm{z}}$ Colonies were measured on 13 dates, and the six dates with statistically significant differences are displayed.

${ }^{y}$ Means not followed by the same letter within the same column are significantly different $(P \leq 0.05)$ by Fisher's least significant difference.

${ }^{\mathrm{x}}$ Area under curve (AUC) value summarizes all 13 dates from 21 Apr. to 16 Oct.

wSodium bicarbonate was applied as spot sprays at $44.2 \mathrm{~g} \cdot \mathrm{L}^{-1}$ on $21 \mathrm{Apr}$. and 5 May.

${ }^{\mathrm{v}}$ Carfentrazone-ethyl was applied on $21 \mathrm{Apr}$. and 5 May (spring) and 19 Sept. and 4 Oct. (spring + fall).

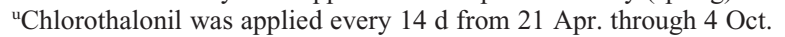

${ }^{\mathrm{t}}$ Chlorothalonil, mancozeb, and thiram mixture was applied at 8.2, 9.9, and $11.6 \mathrm{~kg}$ a.i./ha, respectively, every $14 \mathrm{~d}$ from $21 \mathrm{Apr}$. through 4 Oct.

standard management regime and only when dollar spot reached 5\% plot coverage in the alternative management strategy using the equipment and water rates described for carfentrazone-ethyl. Moss colony size was rated every 2 weeks as described in the 2006 experiment.

Manhattan, KS. In Manhattan, the study was conducted on a green constructed to USGA specifications at the Rocky Ford Turfgrass Research Field. The root zone medium contained $95 \%$ sand and $5 \%$ clay with a $\mathrm{pH}$ of 8.1. The $\mathrm{P}$ and $\mathrm{K}$ levels before the study were 50 and $35 \mathrm{mg} \cdot \mathrm{kg}^{-1}$, respectively. The green had a severe natural infestation of Bryum argenteum (A.J. Shaw, personal communication).

The experiment was arranged as a splitplot, randomized complete-block design with four replications. The whole plot and subplot factors were reversed compared with the CDGA location. Thus, the whole plot $(3.0 \times$ $1.8 \mathrm{~m}$ ) treatments were 1) organic fertilizer only; 2) the alternative regime; 3 ) synthetic fertilizer only; and 4) the standard management regime as described previously. The subplots $(1.5 \times 1.8 \mathrm{~m})$ consisted of the two mowing heights. Six days per week, the entire area was mowed at $4.0 \mathrm{~mm}$ with a Toro Greensmaster 3200 triplex reel mower; then the 3.2-mm plots were mowed with a Toro Greensmaster Flex 18 walk-behind reel mower. Chlorothalonil and carfentrazoneethyl were applied using a handheld $\mathrm{CO}_{2}$ powered boom sprayer equipped with three XR TeeJet 8003VS nozzles at $207 \mathrm{kPa}$ in water equivalent to $828 \mathrm{~L} \cdot \mathrm{ha}^{-1}$. The fertilizers used were the same as those described previously, and they were applied on 14 and 28 May, 11 and 26 June, 9 and 23 July, 6 and 20 Aug., 3 and 17 Sept., and 1 Oct. Irrigation was applied within $12 \mathrm{~h}$ of fertilizer application.

For the standard and alternative management regimes, sodium bicarbonate and carfentrazone-ethyl were applied on 14 and 29 May and 24 Sept. and 1 Oct. Sodium bicarbonate was applied using the rate and method described previously. Carfentrazone-ethyl was applied at $101 \mathrm{~kg} \cdot \mathrm{ha}^{-1}$ using a $\mathrm{CO}_{2^{-}}$ powered boom sprayer equipped with $\mathrm{XR}$ TeeJet $8003 \mathrm{VS}$ nozzles at $241 \mathrm{kPa}$ in water equivalent to $828 \mathrm{~L} \cdot \mathrm{ha}^{-1}$. Chlorothalonil was applied at $8.2 \mathrm{~kg}$ a.i./ha every 2 weeks with
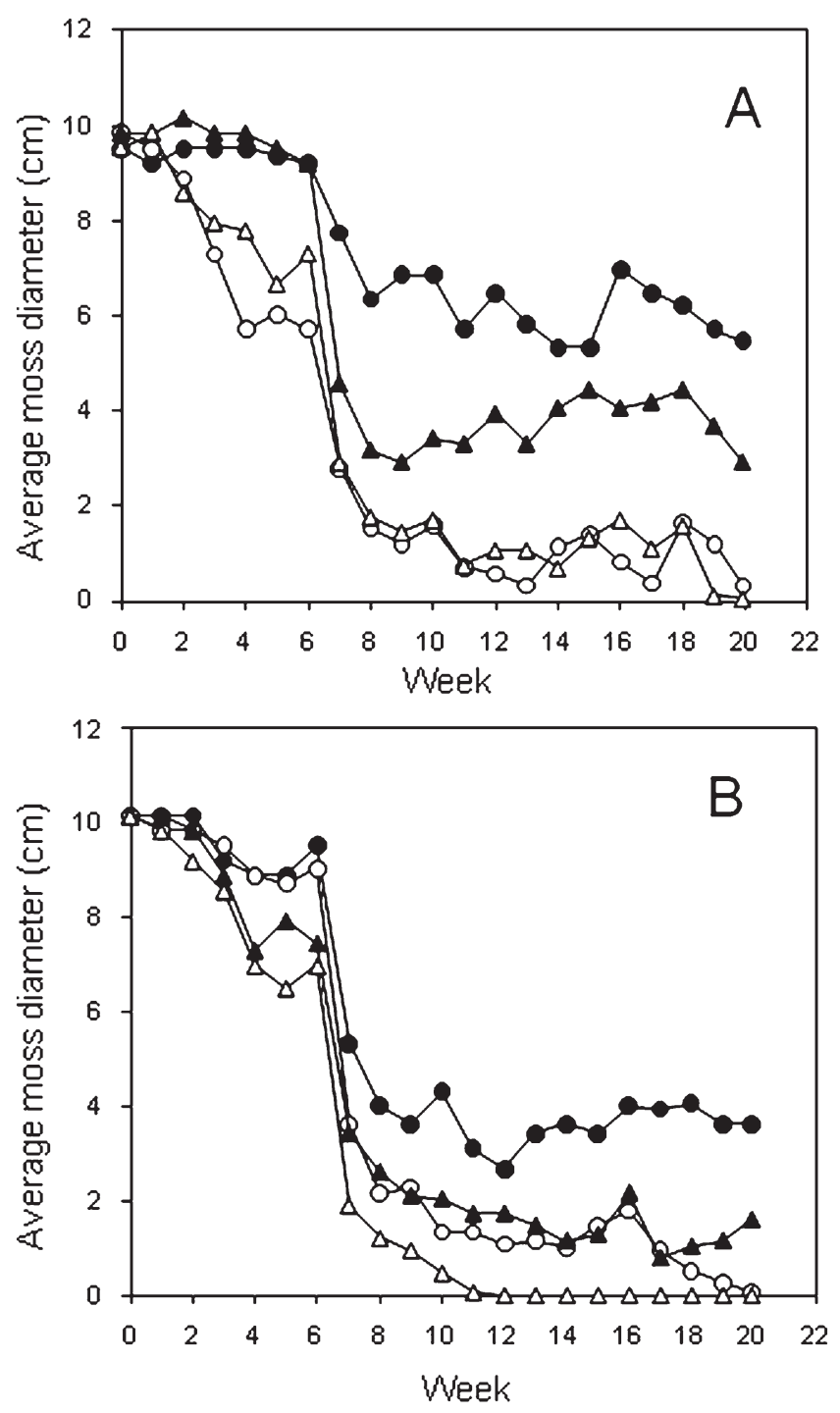

Fig. 1. Effect of management treatments on moss colony diameter in Lemont, IL, in 2008, at mowing heights of 3.2 (A) or 4.0 (B) mm starting on 30 May (Week 0). Closed circles and closed triangles represent organic and synthetic fertilizer only, respectively. Open circles represent alternative management regime, and open triangles represent the standard management regime.

the first application on 14 May and the final application on 1 Oct. in the standard management regime and only when dollar spot reached $5 \%$ plot coverage in the alternative management strategy using the equipment and water rates described for carfentrazoneethyl. Moss coverage was rated every 2 weeks as the percent of each plot infested 
by green moss as visually estimated by two independent raters. The average of the two raters was used for each plot.

Data collection and analysis, 2008. Because individual plots in Manhattan had different initial levels of moss, the percent moss coverage at the beginning of the study (Week 0) was set to $100 \%$ and severity on subsequent dates was scaled accordingly for each plot. At both sites, turfgrass color was rated on a 0 to 9 scale in which $0=$ entire plot area brown or dead; $6=$ minimum acceptable color for a green in summer; $7=$ very good summer color and quality; and $9=$ optimum greenness. Dollar spot severity was assessed as the visual estimation of the percentage of each plot showing dollar spot infection centers. Moss and dollar spot AUC data were subjected to analysis of variance using the PROC MIXED procedure of Statistical Analysis System with fertility/chemical and mowing height treatments and their interactions as fixed effects and block as random effect. Means were separated by the least squares means (LSMEANS) procedure (Statistical Analysis System).

\section{Results}

\section{Initial moss suppression study, 2006}

All treatments reduced moss diameter compared with the untreated control based on AUC analysis in Lemont, IL in 2006 (Table 1). Analysis of moss colony diameters on individual rating dates indicated that two spring applications of sodium bicarbonate effectively suppressed moss growth all season and at a level that was comparable to carfentrazone-ethyl, chlorothalonil, and the fungicide tank mix treatment. Compared with the untreated plots, the chlorothalonil-mancozeb-thiram tank mix and the high rate of chlorothalonil reduced moss colony diameter on 6 of 13 rating dates, and the low rate of chlorothalonil reduced moss colony diameter on five of 13 rating dates. Also, both rates of carfentrazone-ethyl reduced average moss diameter compared with the untreated control, but the $50.5 \mathrm{~g} \cdot \mathrm{ha}^{-1}$ rate was not significantly different from the control on 14 June indicating this lower rate did not suppress moss as quickly as the carfentrazone-ethyl application at $101 \mathrm{~g}$ a.i./ha (Table 1). None of the treatments caused turfgrass phytotoxicity at any time during this study. Based on the 2006 preliminary evaluation, we included spot sprays of sodium bicarbonate $\left(44 \mathrm{~g} \cdot \mathrm{L}^{-1}\right)$ and broadcast applications of carfentrazoneethyl (101 g a.i./ha) as moss control treatments in our evaluation of standard versus alternative putting green management regimes in Lemont, IL, and Manhattan, KS, in 2008.

\section{Standard versus alternative management regimes in Illinois and Kansas, 2008}

Lemont, IL, 2008. In Lemont, bentgrass managed under standard and alternative management regimes had lower moss colony diameters compared with fertilizer-only con- trols (Fig. 1; Table 2). In addition, moss colony diameter was greater in creeping bentgrass receiving organic compared with synthetic fertilizer. There was also a significant interaction between mowing height and moss fertility/chemical used $(P=0.0577)$. Furthermore, the standard and alternative management regimes treatments suppressed moss equally regardless of mowing height. However, in fertilizer-only treatments, the $3.2-\mathrm{mm}$ mowing height supported larger moss colonies than the 4.0-mm mowing height in both management regimes. In the alternatively managed plots, the $5 \%$ dollar spot threshold did not require chlorothalonil application until 11 July, so any early-season suppression was attributed to the sodium bicarbonate alone. Additional threshold-based chlorothalonil applications were required on 28 July, 12 Aug., and 26 Aug. After the 17 Sept. application of sodium bicarbonate, a gray-brown discoloration resulting from tip burn was observed in the creeping bentgrass within $10 \mathrm{~cm}$ of treated moss colonies. By $14 \mathrm{~d}$ after treatment, phytotoxicity was no longer visible and a final sodium bicarbonate application on 1 Oct. did not result in its redevelopment. Except for the first rating date, synthetically fertilized plots always had acceptable color ratings, whereas plots receiving organic fertilizer treatments displayed unacceptable color (less than 6.0) on every date rated except one. There were no significant differences in dollar spot severity based on AUC analysis between the standard and alternative regimes (data not shown).
Manhattan KS, 2008. In Manhattan, the standard management regime reduced moss coverage compared with turf receiving only the synthetic fertilizer (Fig. 2; Table 3). Although the alternative management regime did not significantly reduce moss severity compared with organic fertility alone, it was not significantly different from the standard management regime. The synthetic fertilizer alone was associated with the highest moss severity with moss increasing throughout the season. The 3.2-mm mowing height was associated with an $\approx 1$.6-fold increase in moss severity compared with the $4.0-\mathrm{mm}$ height for all fertility/chemical treatments. In the alternatively managed plots, the $5 \%$ dollar spot threshold was not reached until fall. Chlorothalonil was applied twice, on 19 Sept. (12\% plot blighted by dollar spot) and 1 Oct. (8\% plot damage). Therefore, moss suppression earlier in the season was the result of sodium bicarbonate alone because chlorothalonil was not a factor. Sodium bicarbonate caused noticeable phytotoxicity, visible as tip burn on the creeping bentgrass, $3 \mathrm{~d}$ after the 24 Sept. application; however, the discoloration was no longer visible on 1 Oct. On seven of 11 rating dates, the synthetically fertilized plots had significantly higher color ratings than the plots receiving organic fertilizer (data not shown). There were no significant differences in dollar spot severity based on AUC analysis between the standard and alternative regimes (data not shown).

Table 2. Area under the curve (AUC) analysis of moss colony diameters as influenced by management strategy and mowing height in creeping bentgrass in Lemont, IL, during 2008.

\begin{tabular}{|c|c|c|}
\hline \multicolumn{2}{|l|}{$\begin{array}{l}\text { Treatment } \\
\text { Whole plot (mowing ht) }\end{array}$} & $\mathrm{AUC}^{\mathrm{z}}$ \\
\hline \multicolumn{3}{|l|}{ Whole plot (mowing ht) } \\
\hline $3.2 \mathrm{~mm}$ & & $98.4 \mathrm{a}$ \\
\hline $4.0 \mathrm{~mm}$ & & $82.6 \mathrm{a}$ \\
\hline \multicolumn{3}{|l|}{ Subplot (fertility/chemical) ${ }^{\mathrm{x}}$} \\
\hline Organic fertilizer only (ORG) & & $129.3 \mathrm{a}$ \\
\hline Alternative management (ALT) & & $71.7 \mathrm{c}$ \\
\hline Synthetic fertilizer only (SYN) & & $97.2 \mathrm{~b}$ \\
\hline Standard management (STD) & & $64.0 \mathrm{c}$ \\
\hline \multicolumn{3}{|l|}{ Interactions } \\
\hline Mowing height & Fertility/chemical & \\
\hline $3.2 \mathrm{~mm}$ & ORG & $145.8 \mathrm{a}$ \\
\hline $3.2 \mathrm{~mm}$ & ALT & $63.6 \mathrm{c}$ \\
\hline $3.2 \mathrm{~mm}$ & SYN & $114.3 \mathrm{~b}$ \\
\hline $3.2 \mathrm{~mm}$ & STD & $70.3 \mathrm{c}$ \\
\hline $4.0 \mathrm{~mm}$ & ORG & $112.9 \mathrm{~b}$ \\
\hline $4.0 \mathrm{~mm}$ & ALT & $79.9 \mathrm{c}$ \\
\hline $4.0 \mathrm{~mm}$ & SYNTH & $80.0 \mathrm{c}$ \\
\hline $4.0 \mathrm{~mm}$ & STD & $57.8 \mathrm{c}$ \\
\hline
\end{tabular}

Source of variation

Whole plot (mowing height)

Subplot (fertility/chemical)

Whole plot $\times$ subplot

${ }^{2}$ Area under the curve (AUC) analysis represents cumulative moss severity on 21 weekly assessments between 30 May and 17 Oct. 2008. Means within whole plot, subplot, and interactions sections followed by the same letter are not significantly different (least-squares means, $P \leq 0.10$ ).

yPlots were mowed $6 \mathrm{~d}$ per week at either 3.2 or $4.0 \mathrm{~mm}$.

${ }^{\mathrm{x}}$ ORG plots received biweekly applications of organic fertilizer. ALT plots received biweekly applications of organic fertilizer and two spring and two fall applications of sodium bicarbonate spot sprays at 44.2 $\mathrm{g} \cdot \mathrm{L}^{-1}$ and chlorothalonil at $8.2 \mathrm{~kg}$ a.i./ha when dollar spot reached $5 \%$ severity. SYNTH plots received biweekly applications of synthetic fertilizer. STD plots received biweekly applications of synthetic fertilizer and chlorothalonil at $8.2 \mathrm{~kg}$ a.i./ha and two spring plus two fall applications of carfentrazoneethyl at $101 \mathrm{~g} \cdot h \mathrm{a}^{-1}$. 

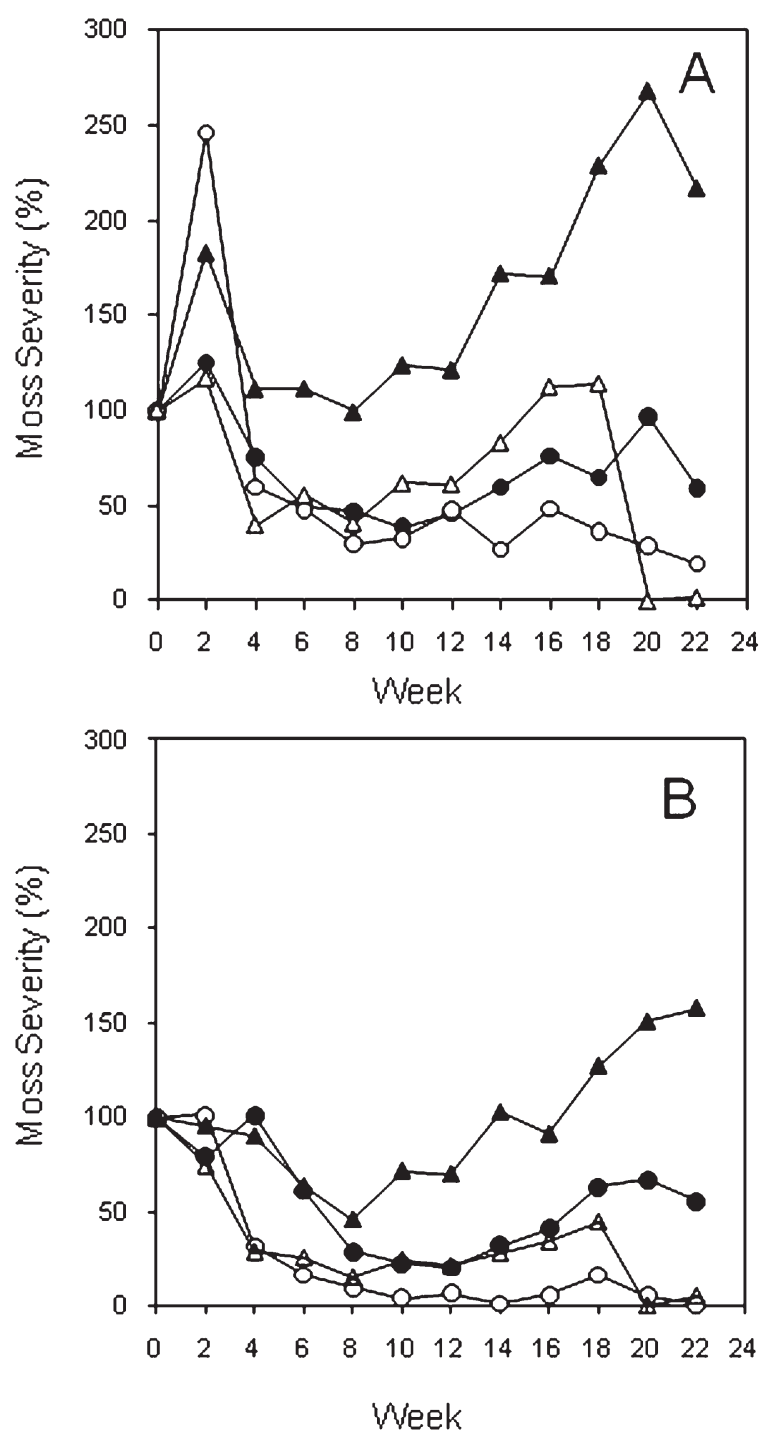

Fig. 2. Influence of management treatments on moss severity in creeping bentgrass mowed at 3.2 (A) or 4.0 (B) $\mathrm{mm}$ in Manhattan, KS, in 2008. Closed circles and closed triangles represent organic and synthetic fertilizer only, respectively. Open circles represent the alternative management regime, and open triangles represent the standard management regime. Moss severity was determined by visually estimating the percentage of each plot covered by green moss. Moss coverage at Week 0 was set to $100 \%$ and severity on subsequent dates was scaled accordingly for each plot.

\section{Discussion}

At both Lemont and Manhattan, use of the alternative green management regime, which included sodium bicarbonate, was as effective in moss suppression as the standard regime that included carfentrazone-ethyl for moss control.

In the 2006 study in Lemont, there were no differences in moss coverage for carfentrazone-ethyl at $101 \mathrm{~g}$ a.i./ha after the fall applications were initiated (19 Sept.), indicating that two applications in the spring were as effective as applications in both spring and fall. Carfentrazone-ethyl applied at $110 \mathrm{~g}$ a.i./ha was not effective when applied during summer and early fall in trials in Wisconsin (Koch and Jung, 2006). Similarly, little to no efficacy was observed in Iowa when carfentrazone-ethyl was applied from July to October on a 'Penncross' creeping bentgrass green using one, three, or four sequential applications at $113 \mathrm{~g}$ a.i./ha (Minner et al., 2007). Under Midwestern conditions, spring applications may be most effective.

Spot treatment of moss using sodium bicarbonate either in solution or dry form is thought to kill moss by desiccation of living cells and is related to an older strategy that used broadcast-applied hydrated lime to damage moss on putting greens (Hummel, 1988; Taylor and Danneberger, 1996). In 2006, there was no phytotoxicity noted after sodium bicarbonate applications, but in 2008, there was some temporary phytotoxicity after one of four applications at each research site. Although spot sprays were used, some of the spray solution drifted onto the turfgrass near the moss colonies. Acceptability of the turf discoloration varies among golf courses. From a practical standpoint, sodium bicarbonate could be useful for low levels of moss in situations that allow target spot applications of individual moss colonies. However, it is important to note that no sodium bicarbonate products are currently labeled for moss control in turfgrass. No phytotoxic effects of carfentrazone-ethyl were ever observed in Lemont or Manhattan. The carfentrazone-ethyl label, however, suggests testing small areas of creeping bentgrass cultivars other than 'Penncross' or 'Crenshaw' before large-scale use. In our experimental conditions, we did not observe phytotoxicity on 'L-93' or ' $\mathrm{G}-2$ ' creeping bentgrass.

In Lemont in 2006, chlorothalonil reduced moss colony diameter compared with the untreated control and was not significantly different from the carfentrazone-ethyl treatments. In 2008, the alternative management plots in Lemont were treated with chlorothalonil for dollar spot four times ( 11 and 18 July and 12 and 26 Aug.) and in Manhattan, the alternative management plots were treated twice (19 Sept. and 1 Oct.) compared with 11 biweekly treatments in plots managed using the standard regime at both sites. In both Lemont and Manhattan in 2008, moss levels were equivalent under the standard and alternative management regimes, indicating that despite the moss-control potential of chlorothalonil observed in 2006, the additional chlorothalonil in the standard regime plots in 2008 did not enhance moss suppression.

At both sites in 2008, mowing height played a role in moss severity. In Lemont, in the fertility-alone treatments, plots mowed at $3.2 \mathrm{~mm}$ had a greater increase in moss colony size compared with plots mowed at $4.0 \mathrm{~mm}$. However, in Lemont, when either sodium bicarbonate or carfentrazone-ethyl was applied, mowing height exhibited no significant influence. In Manhattan, mowing at $3.2 \mathrm{~mm}$ resulted in greater moss severity than mowing at $4.0 \mathrm{~mm}$ across all fertility/ chemical treatments. Lower mowing heights to maximize ball roll speed on golf greens are common and have been associated with moss encroachment (Beard, 2002; Cook et al., 2002). Moss is often observed in greens where turfgrass is thin as a result of mower scalping on ridges and crowns (Nelson, 2007) or the perimeter cleanup laps where excessive equipment wear occurs (Snow, 1984).

In Manhattan, the plots treated with synthetic fertilizer displayed an increase in moss severity of over $200 \%$ compared with the organic fertilizer. Conversely, less moss encroachment occurred in Lemont in plots treated with urea when compared with the organic fertilizer. The potential for soluble $\mathrm{N}$ fertilizers to increase moss spread in creeping bentgrass has not been reported, and more research is needed to determine the effects of a range of $\mathrm{N}$ sources on moss growth in putting greens. Turf quality and color are other essential components of an overall management plan, and, in this study, creeping bentgrass plots receiving synthetic fertilizer had superior color compared with plots receiving organic fertilizer.

The results of these studies demonstrate that spot-spray applications of sodium 
Table 3. Area under the curve (AUC) analysis of percent moss in creeping bentgrass as influenced by management strategy and mowing height in Manhattan, KS, during 2008.

\begin{tabular}{|c|c|}
\hline Treatment & $\mathrm{AUC}^{\mathrm{z}}$ \\
\hline \multicolumn{2}{|l|}{$\overline{\text { Whole plot (fertility/chemical) }}{ }^{y}$} \\
\hline Organic fertilizer only (ORG) & $281.8 \mathrm{~b}$ \\
\hline Alternative management (ALT) & $96.2 \mathrm{~b}$ \\
\hline Synthetic fertilizer only (SYN) & $669.0 \mathrm{a}$ \\
\hline Standard management (STD) & $191.1 \mathrm{~b}$ \\
\hline \multicolumn{2}{|l|}{ Sub plot (mowing ht) ${ }^{\mathrm{x}}$} \\
\hline $3.2 \mathrm{~mm}$ & $379.5 \mathrm{~b}$ \\
\hline $4.0 \mathrm{~mm}$ & $239.5 \mathrm{a}$ \\
\hline \multicolumn{2}{|c|}{ Analysis of variance } \\
\hline \multicolumn{2}{|l|}{ Source of variation } \\
\hline Whole plot (fertility/chemical) & $P=0.0114$ \\
\hline Subplot (mowing height) & $P=0.0015$ \\
\hline Whole plot $\times$ subplot & $P=0.6002$ \\
\hline \multicolumn{2}{|c|}{$\begin{array}{l}{ }^{2} \text { Area under the curve analysis represents moss severity on } 12 \text { biweekly rating dates between } 14 \text { May and } \\
15 \text { Oct. } 2008 \text {. Means within columns followed by the same letter are not significantly different (least- } \\
\text { squares means, } P \leq 0.10 \text { ). } \\
\text { y ORG plots received biweekly applications of organic fertilizer. ALT plots received biweekly applications } \\
\text { of organic fertilizer and two spring and two fall applications of sodium bicarbonate spot sprays at } 44.2 \mathrm{~g} \cdot \mathrm{L}^{-1} \\
\text { and chlorothalonil at } 8.2 \mathrm{~kg} \text { a.i./ha when dollar spot reached } 5 \% \text { severity. SYNTH plots received biweekly } \\
\text { applications of synthetic fertilizer. STD plots received biweekly applications of synthetic fertilizer and } \\
\text { chlorothalonil at } 8.2 \mathrm{~kg} \text { a.i./ha and two spring plus two fall applications of carfentrazone-ethyl at } 101 \mathrm{~g} \text { a.i./ha. } \\
\text { xPlots were mowed } 6 \mathrm{~d} \text { per week at either } 3.2 \text { or } 4.0 \mathrm{~mm} \text {. }\end{array}$} \\
\hline
\end{tabular}

bicarbonate and broadcast applications of carfentrazone-ethyl were effective in suppressing moss on creeping bentgrass greens. When incorporated into standard (synthetic productbased) or alternative (organic fertilizer and threshold-based dollar spot control) management regimes, there was no difference in moss levels in either Lemont, IL, or Manhattan, KS. Studies at both locations indicate that lower mowing heights resulted in greater moss severity.

\section{Literature Cited}

Beard, J.B. 2002. Turfgrass management for golf courses. 2nd Ed. John Wiley \& Sons, Hoboken, NJ.

Boesch, B.P. and N.A. Mitkowski. 2005. Chemical methods of moss control on golf course putting greens. Applied Turfgrass Science. 10.1094/ ATS-2005-1006-01-RV.
Borst, S.M., J.S. McElroy, G.K. Breeden, and M. Flessner. 2009. Cultural practices and silverythread moss control. Golf Course Mgt. 77:137140.

Borst, S.M., J.S. McElroy, A.W. Thoms, and G.K. Breeden. 2008. Different herbicide responses by moss species in creeping bentgrass greens. Golf Course Mgt. 76:82-85.

Buck, W.R. and B. Goffinet. 2000. Morphology and classification of mosses, p. 71-123. In: Shaw, A.J. and B. Goffinet (eds.). Bryophyte biology. Cambridge University Press, Cambridge, UK.

Burnell, K.D., F.H. Yelverton, J.C. Neal, T.W. Gannon, and J.S. McElroy. 2004. Control of silvery-thread moss (Bryum argenteum Hedw.) in creeping bentgrass (Agrostis palustris Huds.) putting greens. Weed Technol. 18:560-565.

Cook, T., B. McDonald, and K. Merrifield. 2002. Controlling moss in putting greens. Golf Course Mgt. 70:103-106.
Dernoeden, P.H. 2002. Creeping bentgrass management: Summer stresses, weeds, and selected maladies. John Wiley \& Sons, Hoboken, NJ.

Dobie, F. 1996. Moss treatment. Northern Ohio Turf. 38:14-15.

Gelernter, W. and L.J. Stowell. 1999. Chemical and cultural controls for moss, Bryum argenteum, on putting greens. Super Journal: PACE Turfgrass Research Institute. p. 1-6. 22 Mar. 2010. <http://www.paceturf.org >.

Happ, K.A. 1998. Moss eradication in putting green turf. USGA Green Section Record. 36:1-5.

Hummel, N.W., Jr. 1988. Cultural and chemical strategies for controlling moss (Bryum argenteum) in creeping bentgrass. Agron. Abst. $80: 152$.

Hummel, N.W., Jr. 1994. Methods for moss control. Golf Course Mgt. 62:106-110.

Koch, P. and G. Jung. 2006. Moss control in Wisconsin: A step in the right direction. The Grass Roots. 35:62-63.

Landschoot, P. and J. Cook. 2005. Options for chemical control of moss in putting greens. 29 June 2009. <http://turfgrassmanagement.psu. edu/chemicalcontrolmoss.cfm>.

Madden, L.V., G. Hughes, and F. van den Bosch. 2007. The study of plant disease epidemics. American Phytopathological Society, St. Paul, MN.

Minner, D.D., R. Rohlfsen, D. Mulder, and F. Valverde. 2007. Moss control on putting greens. Iowa Turfgrass Research Report. p. 1-3.

Nelson, M. 2007. Of moss and men. USGA Green Section Record 45:12-15.

Settle, D.M., R.T. Kane, and G.L. Miller. 2008. Evaluation of newer products for selective control of moss on creeping bentgrass greens. USGA TERO 6:1-6.

Snow, J.T. 1984. A rolling stone and healthy turf. USGA Green Section Record. 22:7-9.

Taylor, T. and K. Danneberger. 1996. Moss on greens: When the rolling stone stops. Golf Course Mgt. 64:53-56.

Turgeon, A.J., L.B. McCarty, and N. Christians. 2009. Weed control in turf and ornamentals. Prentice Hall, Upper Saddle River, NJ.

Yelverton, F.H. 2005. Managing silvery thread moss in creeping bentgrass greens. Golf Course Mgt. 73:103-107. 